\title{
Contribution of rainwater harvesting technologies to rural livelihoods in Zimbabwe: The case of Ngundu ward in Chivi District
}

\author{
Vurayai Mutekwa and Samuel Kusangaya* \\ Department of Geography \& Environmental Science, University of Zimbabwe, PO Box MP167, MT Pleasant, Harare
}

\begin{abstract}
Water has long been regarded as the main limiting resource for crop production in the drought-prone region of sub-Saharan Africa in which Zimbabwe is located. However, the introduction of novel agricultural technologies such as rain-water harvesting (RWH) is seeking to mitigate the effects of these perennial droughts. The successful adoption of such technologies has the potential to alleviate problems faced by resource-poor 'subsistence' farmers. Thus this paper examines the contribution of RWH technologies to rural livelihoods in Zimbabwe and consequently to the sustainability of agriculture and rural livelihoods thereof. The methods employed included a questionnaire survey; key informant interviews and field observations. Benefits of RWH technologies found include an increase in agricultural productivity, enhancing household food security and raising of incomes. The technologies also assisted in improving environmental management through water conservation, reduction of soil erosion and resuscitation of wetlands in the study area. The major constraints facing technology adopters were water distribution problems, labour shortage, water-logging during periods of high rainfall and risk of injury to people and livestock as a result of some of the technologies. However, in an area like Chivi where there are frequent droughts and consequently food shortages among smallholder farmers, the benefits of RWH technology adoption seem to outweigh the costs. It was therefore concluded that RWH technologies are suitable for smallholder farmers in semi-arid areas if they are properly tailored to the conditions of the locality where they are promoted.
\end{abstract}

Keywords: rain-water harvesting, livelihoods, sustainable agriculture

\section{Introduction}

Rain-water harvesting (RWH) technologies are a range of techniques used for collecting, storing and conserving rainfall and surface runoff in arid and semi-arid regions (Boers and BenAsher, 1982). Examples of these techniques include tied ridges, infiltration pits and fanya juus which are all aimed at achieving sustainable agriculture. According to Reijntjes et al. (1992) sustainable agriculture is farming that is ecologically sound, economically viable, socially just and acceptable. Sustainable agriculture aims to achieve permanence, which includes adopting technologies that 'maintain soil fertility indefinitely whilst utilising renewable resources that minimise environmental pollution' (Geier, 1999). In sub-Saharan Africa the potential of RWH for improved crop production received great attention in the late 1970 s and early 1980s in response to widespread droughts that left a trail of crop failures posing serious threats to human and livestock life (Hatibu and Mahoo, 1999; Ngigi, 2003) especially in communal areas, which are characterised by a high population density and appalling household food insecurity. Since then, a number of water conservation projects have been established to combat the effects of drought by improving crop production and in some areas rehabilitating abandoned and degraded land.

Whilst policy-makers in Zimbabwe conscientiously recognised the conspicuous consequences of water shortage in semiarid areas, they had not considered runoff as a solution to water scarcity. Traditionally, drought-tolerant crops were seen as the only solution to erratic rainfall in the drought-prone areas on

* To whom all correspondence should be addressed.

푱 +2634303211 ext 1265; fax: +2634332059 ;

e-mail:kusangay@arts.uz.ac.zw

Received 16 January 2006; accepted in revised form 24 April 2006. one hand, and, on the other, the solution to soil erosion was the safe disposal of 'hazardous' runoff away from croplands. Subsequently, this led to soil and water conservation programmes that focused primarily on water disposal, in areas affected by water shortage. However, since the introduction of RWH technologies these perceptions have changed. Meanwhile, despite the apparent benefits of RWH technologies, they are not yet widely adopted in Zimbabwe (Motsi et al., 2004; Mugabe, 2004), Southern Africa (Rockström, 2000; Ngigi, 2003; Fox et al., 2005) and elsewhere (Li et al., 2004; Prasad et al., 2004; Abu-Zreig et al., 2000) and are a subject of ongoing research (see Walker et al., 2005; Sepaskhah and Fooladmand, 2004). Nevertheless, in recent years, RWH technologies, both traditional and those developed at research stations, have been introduced in some communal areas in Zimbabwe, by non-governmental organisations (NGOs) in collaboration with Agricultural Research and Extension Services (AREX) and technology developers - mostly research stations (Kronen, 1994; Motsi et al., 2004). The crux of the problem then is that RWH technologies are relatively recent technologies in Zimbabwe whose contribution to rural livelihoods is not yet clearly understood. To date, some farmers have been using RWH for crop production, while little is yet known on how they have benefited from the technologies. Thus this paper is aimed at examining the contribution of RWH technologies to rural livelihoods in Zimbabwe.

\section{Methodology}

\section{Study area}

The research was carried out in Chivi district in Masvingo Province (Fig. 1). The district is home to 155442 people (CSO, 2003) 


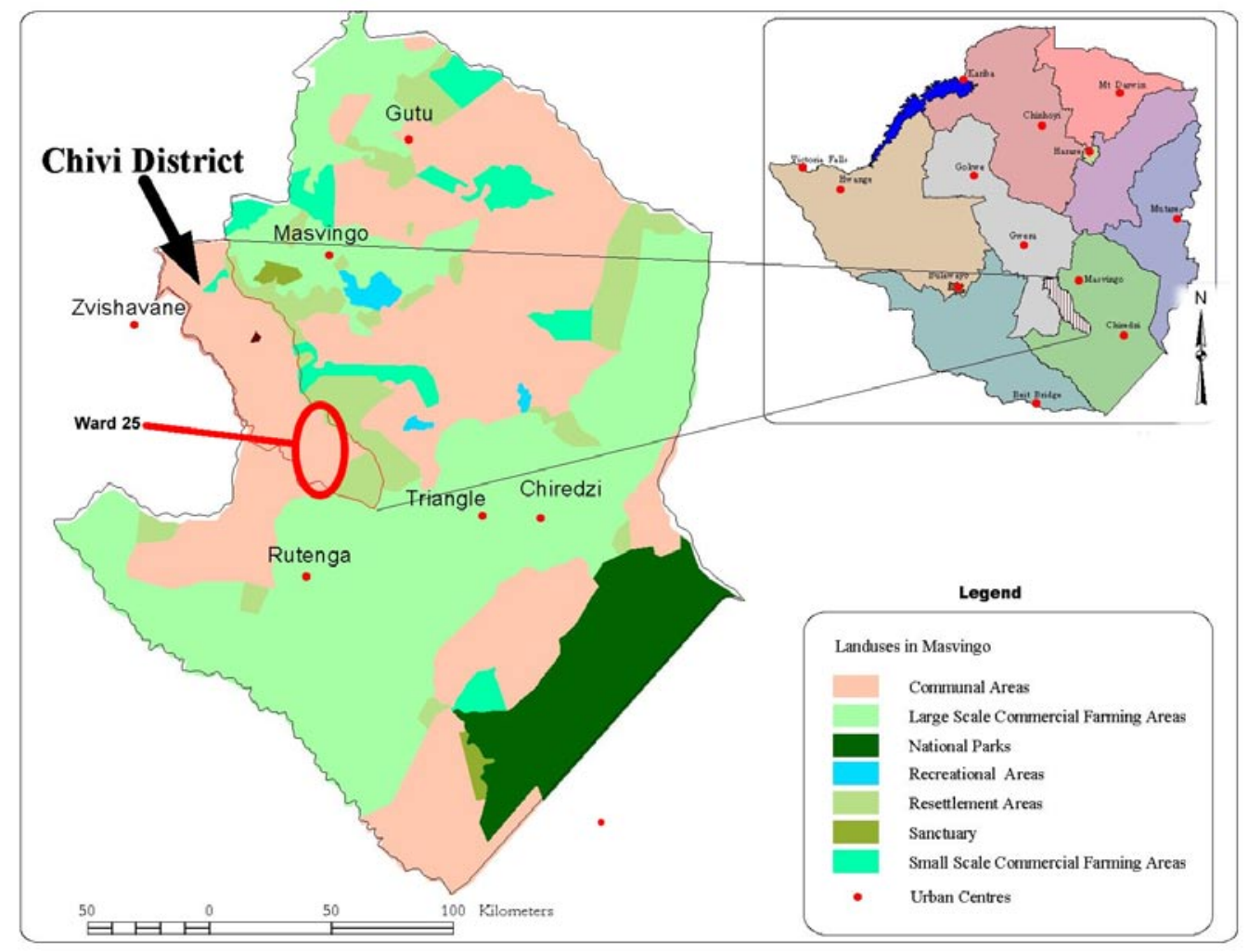

Figure 1

Location of Chivi district

and covers an area of $3534 \mathrm{~km}^{2}$ with an average population density of 43.9 people $/ \mathrm{km}^{2}$. Chivi district receives an average $500 \mathrm{~mm}$ of rainfall per annum. However, this rainfall is erratic and unreliable hence often fails to support rain-fed agriculture resulting in persistent crop failures and subsequent food shortages in the district. Despite this, rain-fed farming continues to be the principal livelihood activity for most farmers with subsistence agriculture forming the mainstay of household economy.

Chivi district was selected for this study because the area, besides being prone to droughts, was also one of the first districts in which RWH technologies were introduced on a large scale (Hagmann et al., 1999; Motsi et al., 2004). Soil and water conservation activities were promoted by a number of organisations including, Intermediate Technology Development Group (ITDG) food security project, German Technical Development Agency (GTZ) conservation tillage project and Agritex (Murwira and Hagmann, 1996). The NGOs named above operate(d) in smaller administrative units (wards) within the district. Each ward is a clearly defined region with a total population ranging approximately, from 6000 to 10000 people. As a result there are a number of wards where RWH technologies have been adopted, with Ngundu ward having a long history (over 5 years) of RWH (Hagmann et al., 1999; Chivi District AREX officer, 2004). Furthermore, Ngundu ward and the 3 case study villages (Pedzisai 1; Nduna 1 and Guti) in their entirety are located in the communal areas which were targeted in this study because of the perennial food insecurity experienced in communal areas like these. Ngundu ward is approximately $146 \mathrm{~km}^{2}$ with a total population of 9031 people and a population density of about 61.8 people $/ \mathrm{km}^{2}$ which is one of the highest population densities in the district. The average household size in the ward is five persons (CSO, 2003). In the study area, the farmers practice the following rain-water harvesting techniques: fanya juus; tied ridges; macro-catchments and graded contours.
These techniques have been widely described elsewhere (see Elwell, 1993; AGRITEX, 1998; Ojasvi et al., 1999; Abu-Zreig at al., 2000; Ngigi, 2003; Motsi et al., 2004; Mugabe, 2004).

\section{Interviews and questionnaire survey}

Formal interviews were conducted with AREX officers, local NGOs, district officers and other institutions involved in RWH in the district. Questionnaires were administered to farmers who had adopted one or more RWH technologies, particularly in Pedzisai 1, Nduna 1 and Guti villages. For pre-testing, the questionnaire was self-administered to 8 respondents $(12.9 \%$ of total study respondents) in Mushagashe, a small-scale farming area adjacent to Ngundu ward in the north east. The pre-test was conducted to identify problems that would occur when administering the questionnaire in the field and resources needed for the planned study. It was also carried out to assess the length of time to be spent per respondent, clarity of questions and to facilitate training of assistants in as many elements of the research process as possible.

In the study area, information provided by chairpersons of the local RWH promotion institutions showed that there were 32 rain-water harvesters in Pedzisai 1, 19 in Guti and 15 in Nduna 1, giving a total of 66 harvesters (Fig. 2 and Table 1).

\begin{tabular}{|l|c|c|c|}
\hline \multicolumn{5}{|c|}{ TABLE 1 } \\
Target population in the 3 case study villages \\
\hline Village & $\begin{array}{c}\text { Number of RWH } \\
\text { Households }\end{array}$ & $\begin{array}{c}\text { Households } \\
\text { in the village }\end{array}$ & Percentage \\
\hline Pedzisai 1 & 32 & 113 & $28 \%$ \\
\hline Guti & 19 & 97 & $19.6 \%$ \\
\hline Nduna 1 & 15 & 102 & $14.4 \%$ \\
\hline Total & 66 & 312 & $21.1 \%$ \\
\hline
\end{tabular}




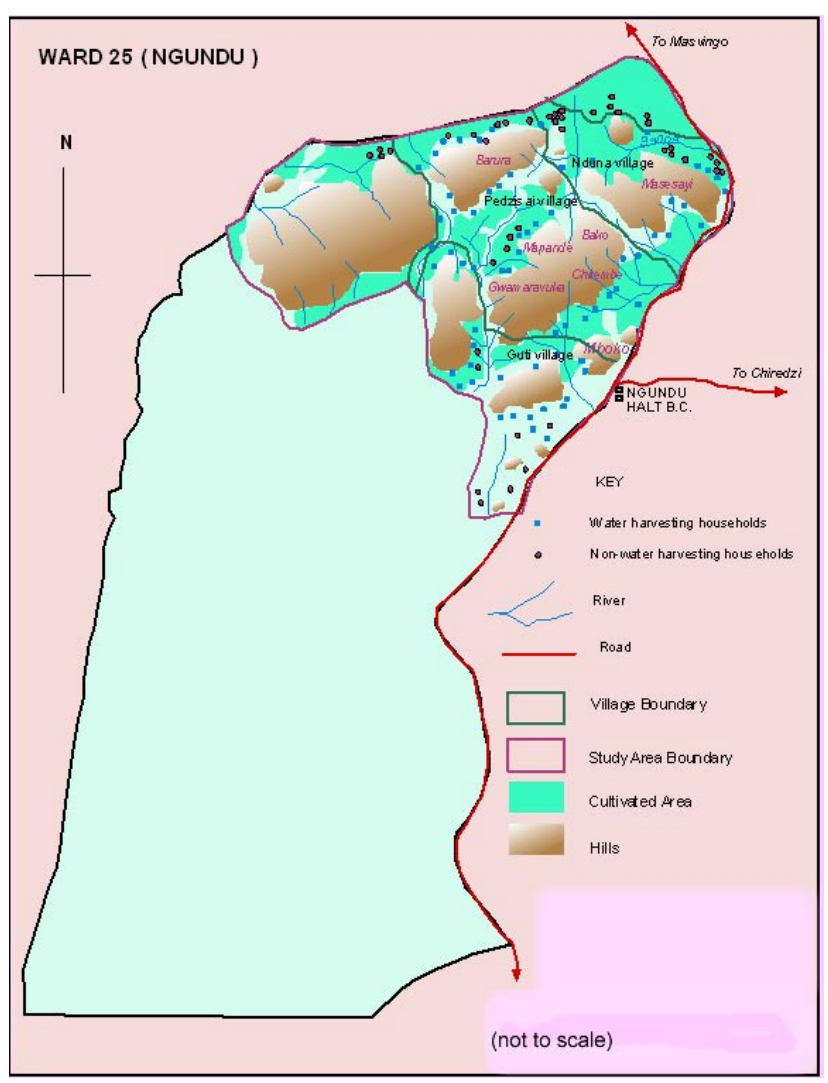

Figure 2

Ngundu ward and villages

Since the RWH adopters were relatively few, it was difficult to identify or distinguish the homestead of the rain-water harvester from that of the non-adopter, prompting the use of the snowball identification method. According to Atkinson and Flint (2001) snowball identification involves identifying respondents who then refer researchers to other respondents (Fig. 3). Furthermore, Faugier and Sargeant (1997) state that this approach can be viewed as a response to overcoming the problems associated with sampling concealed populations and Thomson (1997) asserts that it takes advantage of social networks of identified respondents to provide a researcher with an ever-expanding set of potential contacts. This process is based on the assumption that a 'bond' or 'link' exists between the initial sample and others in the same target population, allowing a series of referrals to be made within a circle of acquaintances (Berg, 1988). In this study it was used only as a means of identifying respondents practicing rain-water harvesting (the target population), without having to visit all the households in the study area.

In the study area, the first RW harvester was identified with the help of an AREX officer. This farmer then led the field workers to the next farmer who did the same and so on. This type of identification was possible since the RW harvesters knew each other well within the locality as they either lived in the same or adjacent village, belonged to the same farmers' organisation, shared equipment or met on field-days.

\section{Results and discussion}

A total of 62 farmers were interviewed out of a possible 66 farmers, the other 4 not being at their homesteads during the

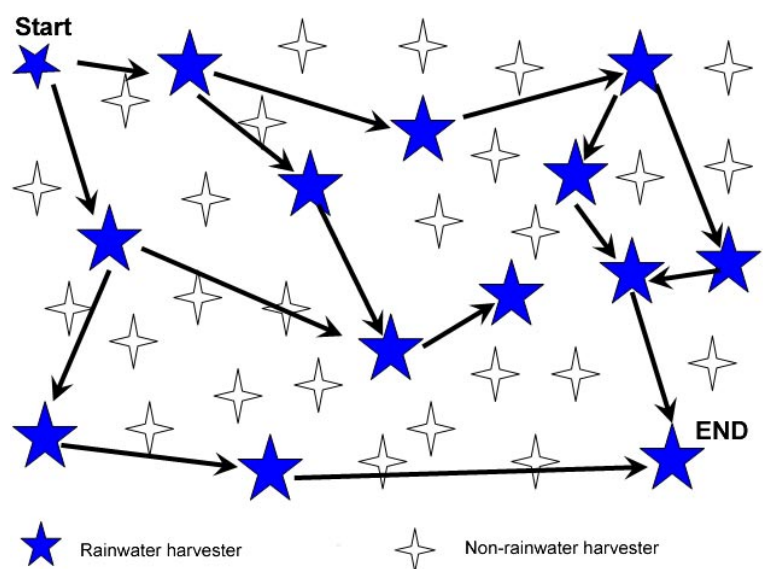

Figure 3

Snowball sampling illustration (after Blaxter et al., 1999)

duration of the study. These farmers adopted a wide spectrum of RWH techniques, with the most common techniques being infiltration pits adopted by $61 \%$ of the households (Fig. 6). These were followed by fanya juus (34\%); tied ridges (27\%); macrocatchments $(10 \%)$ and graded contours $(7 \%)$. Infiltration pits were a popular choice as they seem to retain more moisture in the soil and allowed the growing of a variety of crops. In some instances, farmers adopted more than one RWH technique thereby also growing more crop varieties.

\section{Crops grown under RWH technologies}

RWH enabled the growing of various crops in the villages (Table 2) during the 2003-2004 season.

\begin{tabular}{|c|c|c|}
\hline \multicolumn{3}{|c|}{$\begin{array}{c}\text { TABLE } 2 \\
\text { Crops grown under RWH technologies } \\
\text { in the 2003-2004 season }\end{array}$} \\
\hline Crop & $\begin{array}{c}\text { Number of } \\
\text { farmers }\end{array}$ & $\begin{array}{l}\% \text { of farmers } \\
(n=62)\end{array}$ \\
\hline Maize & 62 & 100 \\
\hline Vegetables & 48 & 77.4 \\
\hline Sugar-cane & 37 & 59.7 \\
\hline Bananas & 36 & 58.1 \\
\hline Groundnuts & 29 & 46.8 \\
\hline Rice & 24 & 38.7 \\
\hline Wheat & 12 & 19.4 \\
\hline Beans & 11 & 17.7 \\
\hline Cotton & 10 & 16.1 \\
\hline
\end{tabular}

All the farmers interviewed grew maize under at least one of the RWH technologies they had adopted. Maize is a staple food crop hence household food shortage is synonymous with the shortage of maize grain. Interviewed farmers also grew other cash crops such as sugar-cane $(59.7 \%)$ and vegetables (77.4\%) for income generation. Nevertheless, only a few farmers grew cotton (16.1\%) under RWH because it is a 'droughttolerant' crop that usually does well under rain-fed dry-land farming. Overall, the RWH technologies adopted by farmers in the three study villages are small-scale in nature making them well suited to operation by individual households, which are the primary units of agricultural production in the communal areas. 


\section{Main sources of household income}

About $75.8 \%$ of the RW harvesters indicated that they depend on farming as the main source of income followed by formal employment $(17.7 \%)$, that is, the percentage of the working population employed within the formal economy, have access to workers rights and are protected by government laws. Most of the formal employees were employed by the rural district council and the majority are teachers at local primary and secondary schools. Remittance income provided sustenance to about $1.6 \%$ of the households and $4.9 \%$ depended on the other income sources like crafts and trading in clothing among other means. Thus farming was found to be the main means of sustenance and RWH has enhanced agricultural sustainability for most of the households in the study area.

\section{Costs of RWH technologies}

The two main types of costs associated with RWH technologies are the initial investment costs and operating costs. These cover the cost of tools, labour and training associated with investment and operating the technologies. About $74 \%$ of the respondents pointed out that they did not incur any initial capital investment costs and were currently experiencing negligible operational costs. By and large, the support farmers received from GTZconservation tillage programmes in the form of the provision of agricultural resources like 'ridgers' for making tied ridges and donkey-draught power, made the adoption of the technologies less expensive. During the inception stages, farmers acquired knowledge on RWH in a number of ways. About $44 \%$ of the farmers learnt about the technologies through look-and-learn tours that were being advocated and demonstrated by external institutions (NGOs). Others indicated that they learnt about them from neighbouring farmers and local AREX officers, both of which involved minimal direct costs to the farmer.

\section{Benefits associated with the adoption of RWH technologies}

The benefits that have accrued to the RWH technology adopters can be categorised into socio-economic and environmental benefits. Within these categories both direct and indirect benefits can be identified. The latter are commonly referred to as externalities.

\section{Environmental benefits}

Both key informants and the interviewed farmers alluded to a number of benefits that have and shall continue to accrue to the environment as a result of the establishment of the RWH technologies. Fig. 4 shows some of the benefits to the environment brought about by the adopted RWH technologies.

Eight seven percent (87\%) of the interviewed farmers were aware that the technologies reduce soil erosion in their fields through harvesting runoff water. Furthermore, not only were water and soil conservation benefits cited as resulting from RWH, but also the possibility of groundwater recharge (Fig. 4) which was evident from the now more reliable wells used for watering vegetables. However, to the farmers the environmental benefits are externalities because they did not adopt them primarily to conserve the environment, but because of the direct livelihood benefits that accrued to them as individual households.

In addition, other environmental benefits cited included the improvement of pasture quality, further reducing the likelihood

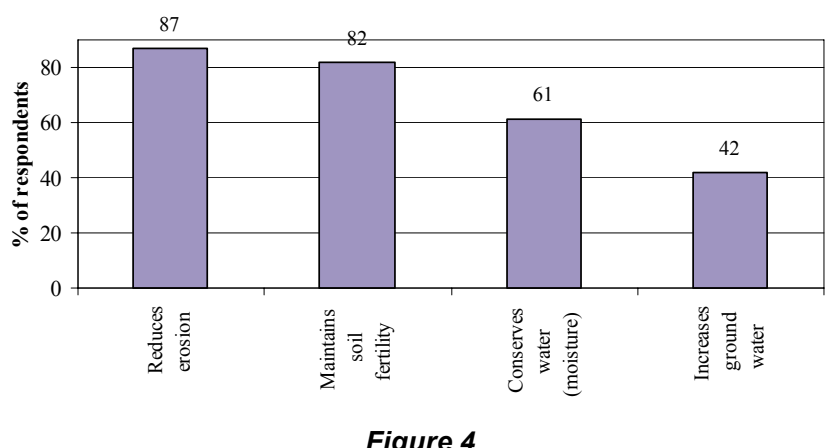

Figure 4

Environmental benefits of RWH technologies

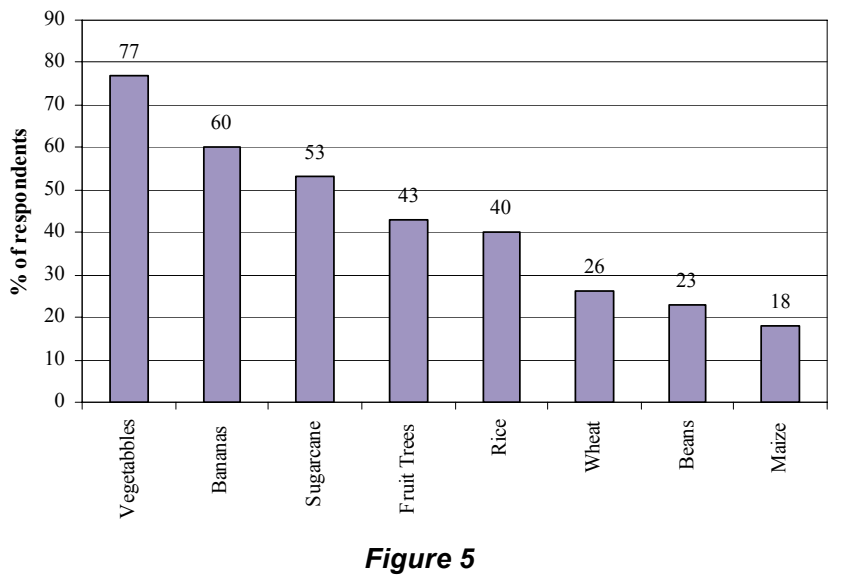

Crops resulting from the adoption of RWH technologies

of overgrazing since tall grass is now growing in place of dwarf grass. Moreover, the grass is at times cut and used as hay during the dry season. This further improves the quality of livestock and guards against overgrazing and possibly further environmental degradation such as erosion. Meanwhile, wetlands that had become a rare phenomenon in the area have been resuscitated and wetland ecology is becoming evident.

Furthermore, the adoption of the RWH technologies has led to changes in cropping patterns such as the introduction of new crops, improved tillage methods and the growing of two or more crops during the same season including winter cropping. Figure 5 shows the crops that are now being grown by the farmers as a direct result of the adoption of RWH technologies.

From the survey it was established that some crops that used to be alien in the area have now been introduced and are being grown on a regular basis under different RWH techniques (Fig. 6). These include bananas (60\%), sugar-cane (53\%) rice (40\%) and horticultural crops grown by $77 \%$ of the RWH adopters. Vegetables grown range from leaf vegetables, tomatoes, onions and curry, grown in the fields after harvesting the main food crops. These crops were now being grown because water yields from the wells have become more reliable and in some areas permanent with some fields having been converted into wetlands. Vegetables have become more attractive to several farmers because they have a ready market at the local business centre. Overall, these crops have enhanced household food security for the farmers.

\section{Socio-economic benefits}

Some adopters $(31 \%)$ formed labour groups in order to reduce the amount of time spent during the initial establishment of the RWH technologies. These were predominantly those who had 


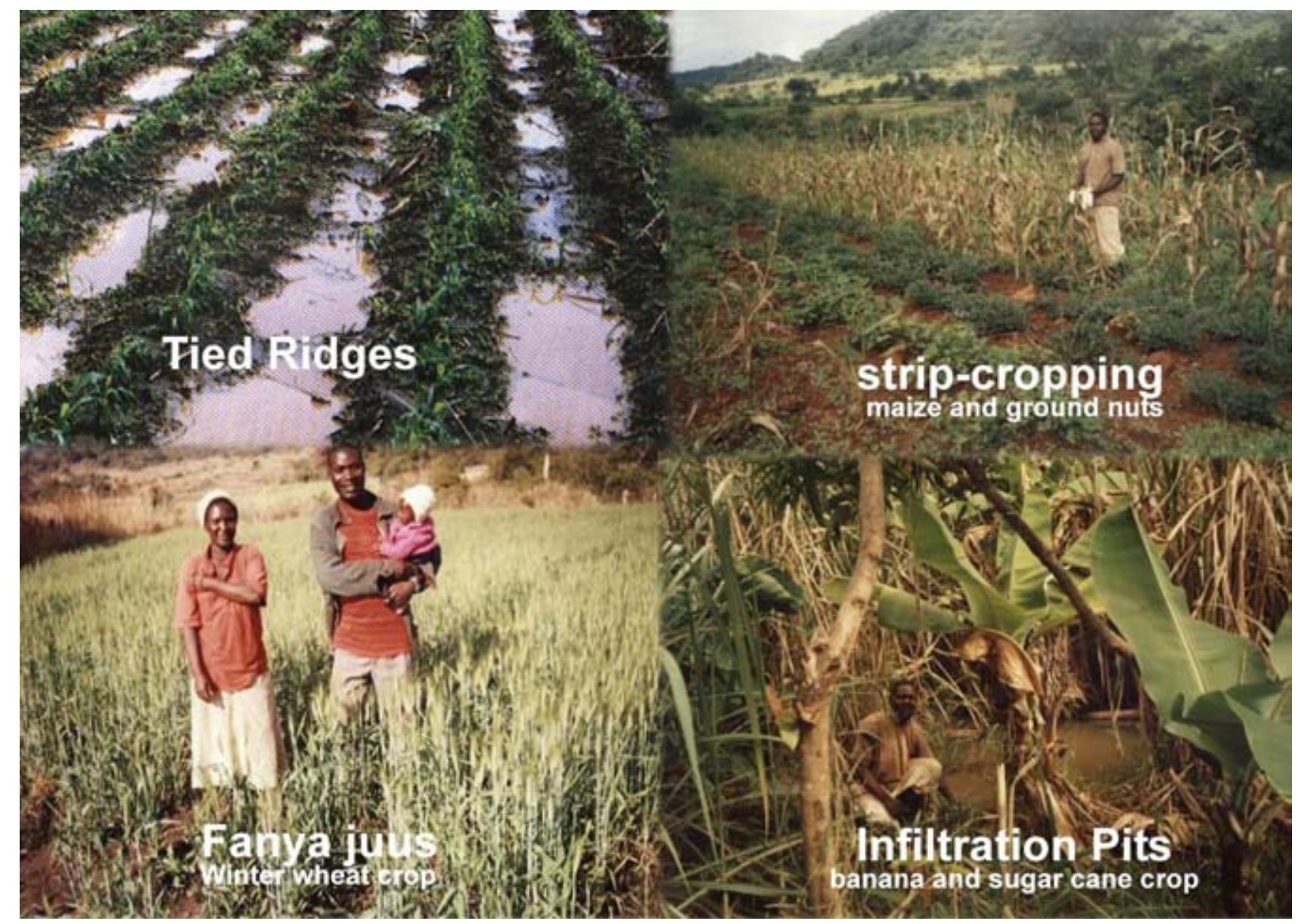

Figure 6

Some RWH techniques and crops grown

less than 4 household members available to provide labour on the farm. Alternatively, some farmers indicated that they work in groups in order to offset the problems of labour and equipment shortages. One such farmer had the following to say about RWH:

'These technologies have taught us to work together.

We learn from each other, share labour and tools.

We have already formed permanent labour clubs.

Otherwise as individual households, we would not

manage,

\section{$R W$ harvester in Pedzisai 1 village.}

The above seems to demonstrate that RWH technologies have to a certain extent enhanced cohesiveness of rural social capital in the form of reciprocity, togetherness and co-operation in sharing equipment, labour and ideas. Household labour availability is therefore important, but where it is inadequate, labour groups can fill the gap or the technologies can be adopted gradually to reduce labour demands at once.

Some farmers $(16 \%)$ pointed out that they grow wheat in winter because their fields can now hold enough moisture to support another crop during the dry season. Of the $27 \%$ farmers who adopted tied ridges, $18 \%$ grow rice since the ridges ensure uniform moisture distribution in the field. They also promote inter-cropping (strip-cropping) (Fig. 6) of mainly maize and rice, whereby rice is grown in the furrows whilst maize occupies the ridges. Other crops that have become quite popular with the RWH farmers are bananas and sugar-cane. The main reason

\begin{tabular}{|c|c|c|}
\hline \multicolumn{3}{|c|}{ TABLE 3 } \\
$\begin{array}{c}\text { Number of crops gown on rotational } \\
\text { basis in one calendar year }\end{array}$ \\
\hline $\begin{array}{c}\text { Number } \\
\text { of crops } \\
\text { grown }\end{array}$ & $\begin{array}{c}\text { Number of } \\
\text { respondents }\end{array}$ & Percentage \\
\hline 1 & 7 & $11 \%$ \\
\hline 2 & 43 & $69 \%$ \\
\hline 3 & 8 & $13 \%$ \\
\hline 4 & 4 & $7 \%$ \\
\hline Total & $\mathbf{6 2}$ & $\mathbf{1 0 0 \%}$ \\
\hline
\end{tabular}

given for the growing of these crops was that they are high-value crops that have a ready market at the nearby Ngundu Halt business centre. Indirectly, this has led to increased incomes as they sell their products, improvement of the farmers' household food security, diversification in diet and therefore overall improvement of the quality of life among the RWH adopters.

The adoption of the RWH technologies has also enabled the farmers to practice relay cropping on their farms (Table 3) whereby one crop is grown immediately after the other.

With $89 \%$ of the RWH farmers indicating that they are now able to grow at least 2 crops on a rotational basis in one calendar year, it shows that the farmers are now intensively utilising their land. For example, the Kubatana Club chairman pointed out that they no longer regard their pieces of land as small since RWH technologies enabled them to practice intensive farming. Conse- 
quently, farm productivity has also increased to the extent that some farmers are now able to sell some of the main food crops they used to produce in quantities that could not even meet family requirements. Table 4 shows farm productivity for selected crops harvested and sold by the RWH farmers.

\begin{tabular}{|c|c|c|}
\hline \multicolumn{3}{|c|}{$\begin{array}{c}\text { TABLE } 4 \\
\begin{array}{c}\text { Farm productivity for selected crops harvested } \\
\text { and sold by RWH farmers }\end{array}\end{array}$} \\
\hline Crop & $\begin{array}{c}\text { Average } \\
\text { harvested }\end{array}$ & Average sold \\
\hline Maize & $2952 \mathrm{~kg}$ & $2061 \mathrm{~kg}$ \\
\hline Groundnuts & $540 \mathrm{~kg}$ & $288 \mathrm{~kg}$ \\
\hline Wheat & $297 \mathrm{~kg}$ & $144 \mathrm{~kg}$ \\
\hline Rice & $126 \mathrm{~kg}$ & $\begin{array}{l}\text { Not sold (kept for household } \\
\text { consumption) }\end{array}$ \\
\hline Cotton & $378 \mathrm{~kg}$ & $378 \mathrm{~kg}$ \\
\hline
\end{tabular}

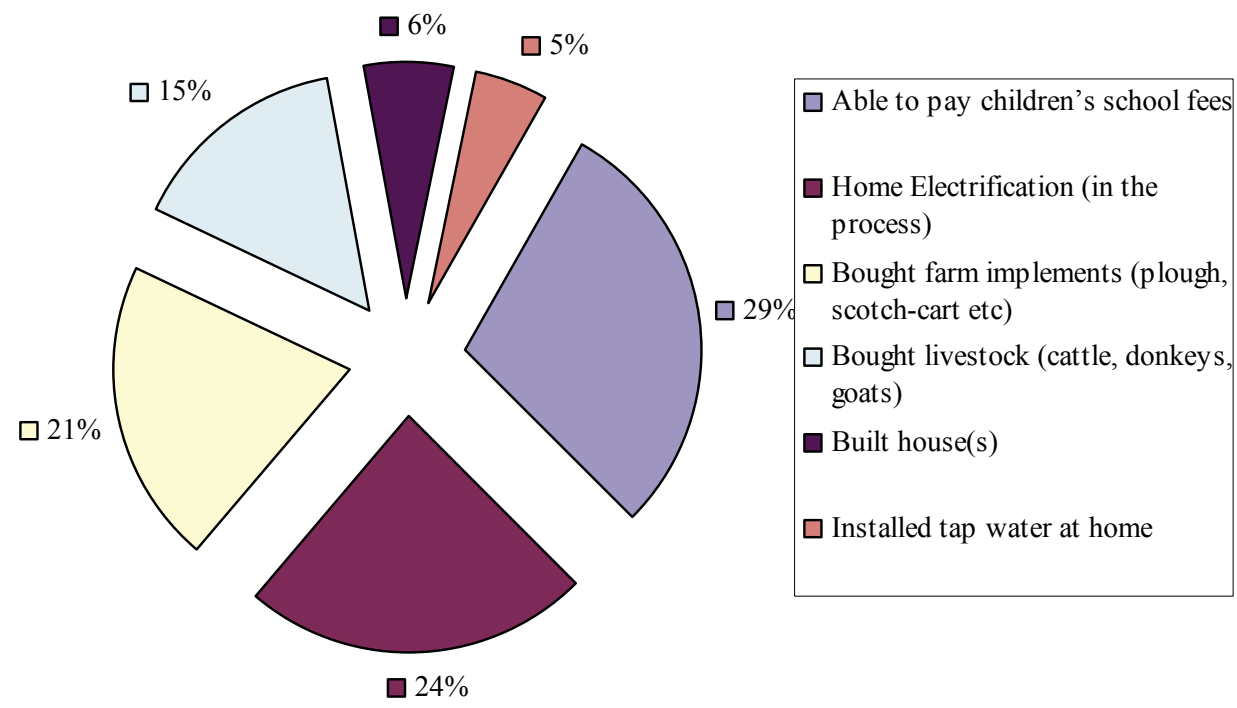

Figure 7

Other livelihood benefits

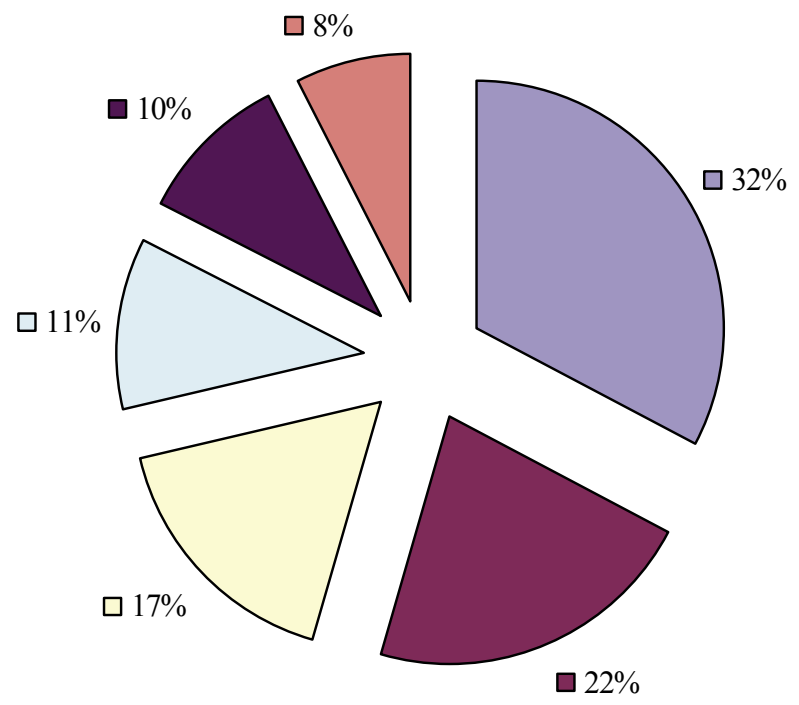

$\square$ Waterlogging
$\square$ Labour
$\square$ Rater distribution
people
No problem
$\square$ Time

Figure 8

Problems associated with RWH technology
For the farmers, the basic food crops like maize and groundnuts are now being produced in quantities that meet not only household food requirements, but produce a surplus that can be sold. The RWH farmers can now afford to sell an average of $2061 \mathrm{~kg}$ and keep an average about $891 \mathrm{~kg}$ for household consumption of the maize produced. Of all the respondents interviewed, $40 \%$ of the farmers are now net maize sellers. Furthermore, rice is grown solely for consumption (Table 4). This shows the ability of the technologies to increase agricultural productivity among the smallholder farmers, enhancing sustainable agriculture as well as improving household food security.

\section{Other livelihood benefits}

The rain-water harvesters pointed out that they have realised other benefits since they adopted the technologies (Fig. 7). Since the actual annual incomes obtained from all agricultural products per year could not be determined with any degree of certainty due to lack of household level record keeping, the benefits derived from agricultural incomes were regarded as indicators of the incomes that the farmers were realising. As shown in Fig. 7 the farmers have realised some gains since the adoption of the technologies. About $29 \%$ of the farmers indicated that they could now pay their school children's fees without problems. For example, approximately, $86 \%$ of the households in Pedzisai 1 village are in the process of electrifying their homes and similarly another $66 \%$ from the same village pointed out that they bought farming resources (draught-cattle, ploughs and scotch-carts).

This is evidence that there has been an improvement in the livelihoods of the technology adopters in terms of their standard of living. Furthermore, provision of clean water is an important indicator of the standard of living in rural communities. The fact that some of the technology adopters managed to install a reliable and safe source of water indicates an improvement in their quality of life. The improvement in housing, sources of energy and agricultural resources has benefits not only to the people but also to the environment.

The benefits of the technologies can also be envisaged by looking at the change in the problems that are being regarded by the farmers as critical and therefore needing attention. Forty three percent $(43 \%)$ of the farmers now regard transport of their produce, par- 
ticularly horticultural crops, as their major problem especially to the distant markets like Chiredzi and Masvingo, which are more than $80 \mathrm{~km}$ away. Ngundu Halt business centre was regarded as too small a market for the products from the surrounding farmers resulting in the products fetching low prices due to low demand.

\section{Problems associated with the adoption of RWH technologies}

A number of problems associated with the RWH technologies (highlighted in Fig. 8) ranged from presentation of risk of injury to people and livestock, demand for labour, time, and water-logging. The most prominent problem was water-logging mainly because the study was carried out during a high rainfall period.

Despite the above cited problems, it was encouraging to note that of all the farmers who had adopted one form of RWH or the other, none had opted out, showing that they were benefiting on one way or the other. Maybe this would encourage other farmers to join RWH technologies. Furthermore, the farmers who have adopted RWH have devised ways of dealing with some of the cited problems, for instance, formation of labour groups to mitigate against labour shortage.

\section{Conclusion}

The study was carried out to assess the adoption of RWH technologies and their contribution to sustainable agriculture and rural livelihoods. A number of technologies have been adopted by the farmers in the study area to complement rain-fed agriculture. Overall, it can be concluded that the adoption of RWH technologies increases agricultural production, improves the people's standard of living and reduces environmental degradation. In most cases, communal farmers are constrained by inadequate capital, therefore RWH enables farmers to break out of the cycle of poverty, and are now able to purchase equipment and improve their livelihoods. In an area like Chivi and all other drought-prone areas, where there are frequent droughts leading to perennial food shortages among smallholder farmers, RWH technologies are suitable as in most cases such farmers lack the capital to establish, for example, irrigation schemes. Similarly, RWH is ideal for farmers in areas where irrigation is difficult or impossible to establish. Nevertheless, the technologies need to be properly tailored to the socio-economic and physical conditions of the locality where they are being promoted. There is therefore the need to make people conscious of the different technologies and their benefits, then mobilise and train the communities so that they can appreciate RWH and adopt these techniques to improve their livelihoods. By and large, development that empowers local communities has a greater chance of achieving sustainable resource management as the communities take direct ownership of the developments. Moreover, the spread of RWH technologies should be encouraged as they can significantly improve agricultural productivity in other dry regions.

\section{References}

ABU-ZREIG M, ATTOM M and HAMASHA N (2000) Rainfall harvesting using sand ditches in Jordan. Agric. Water Manage. 46 (2) 183-192. Elsevier.

ATKINSON R and FLINT J (2001) Accessing hidden and hard-to-reach populations: Snowball research strategies. Social Research Update, Issue 33. University of Surrey. http://www.soc.surrey.ac.uk/sru SRU33.htm (accessed on 25 August 2005).
BERG S (1988) Snowball sampling. In: Kotz S and Johnson NL (eds.) Encyclopaedia of Statistical Sciences. Vol. 8.

BLACKIE MJ (1994) Realising smallholder agricultural potential. In: RUKUNI M and EICHER CK (eds.) Zimbabwe's Agricultural Revolution. University of Zimbabwe, Harare.

BLAXTER L, HUGHES C and TIGHT M (1999) How to Research. Viva Books Pvt Ltd. New Delhi.

BOER THM and BEN-ASHER J (1982) A review of rainwater harvesting. Agric. Water Manage. 5 145-158.

CENTRAL STATISTICAL OFFICE (2003) National Census Profile. Government of Zimbabwe Printers, Harare, Zimbabwe.

CRITCHLEY WRS and REIJ C (1989) Water harvesting for plant production: In: Hatibu N and Mahoo H (1999) Rainwater Harvesting Techniques for Agricultural Production: A Case for Dodoma, Tanzania. Sokoine University of Agriculture, Morogoro.

DEPARTMENT OF AGRICULTURAL RESEARCH AND EXTENSION SERVICES (AGRITEX) (1998) Learning Together through Participatory Extension: A Guide to an Approach Developed in Zimbabwe. AGRITEX, Harare.

ELWELL HA (1993) Development and Adoption of Conservation Tillage Practices in Zimbabwe, in Soil Tillage in Africa: Needs and Changes. FAO Soils Bull. 69. Soil Resources, Management and Conservation Service, Land and Water Development Division, FAO, Rome.

FAUGIER J and SARGEANT M (1997) Sampling hard to reach populations. J. Adv. Nursing. 26 790-797.

FOX P, ROCKSTRÖM J and BARRON J (2005) Risk analysis and economic viability of water harvesting for supplemental irrigation in semi-arid Burkina Faso and Kenya. J. Agric. Syst. 83 231-250. Elsevier, UK.

GARDUNO MA (1981) Research methodologies for in-situ rainwater harvesting in rainfed agriculture. In: Dutt GR, Hutchinson CF and Garduno MA (eds.) Rainfall Collection for Agriculture in Arid and Semi-Arid Regions. Commonwealth Agriculture Bureaux, London.

GEIER B (1999) Organic Agriculture - Sustainability Put into Practice. In: Fairclough AJ (ed.) Sustainable Agriculture Solutions. Novello Press Ltd, London. 59-61.

HAGMANN J, CHUMA E, MURWIRA K and CONNOLLY M (1999) Putting process into practice: Operationalising participatory extension. Agricultural Research and Extension Network Network Paper No. 94, AGREN, UK.

HATIBU N and MAHOO H (1999) Rainwater Harvesting Techniques for Agricultural Production: A Case for Dodoma, Tanzania, Sokoine University of Agriculture, Morogoro. http://www.atnesa.org/contilhatibu-waterharvesting.TZpd (accessed on 25 September 2005).

KRONEN M (1994) Water harvesting and conservation techniques for small holder crop production systems. J. Soil Till. Res. 32 71-76. Elsevier.

LI XIAO-LAN, ZHONG-KUI XIE and XIANG-KUI YAN (2004) Runoff characteristics of artificial catchment materials for rainwater harvesting in semi arid regions of China. Agric. Water Manage. 65 211-224.

MOTSI KE, CHUMA E and MUKAMURI BB (2004) Rainwater harvesting for sustainable agriculture in communal lands of Zimbabwe. Phys. Chem. Earth (B) 29 1069-1073.

MUGABE FT (2004) Evaluation of the benefits of infiltration pits on soil moisture in semi-arid Zimbabwe. J. Agron. 3 (3) 188-190. Asian Network for Scientific Information.

MURWIRA K and HAGMANN J (1996) Indigenous SWC in Southern Zimbabwe: A study of techniques, historical changes and recent developments under participatory research and extension. In: Reij C, Scoones I and Toulmin C (eds.) (1996) Sustaining the Soil - Indigenous Soil and Water Conservation in Africa. EarthScan, London. 248 pp.

MUTISI F (2004) Personal communication, Chivi District AREX officer, Department of Agricultural Research and Extension Services.

NGIGI S N (2003) What is the limit of up-scaling rainwater harvesting in a river basin? Phys. Chem. Earth 28 943-956. Elsevier.

OJASVI PR, GOYAL RK and GUPTA JP (1999) The macro-catchment water harvesting technique for the plantation of jujube (Zizyphus mauritiana) in an agroforestry system under arid conditions. Agric. Water Manage. 41 139-147. Elsevier. 
PACEY A and CULLIS A (1986) Rainwater harvesting: The collection of rainfall and runoff in rural areas. In: Hatibu $\mathrm{N}$ and Mahoo $\mathrm{H}$ (1999) Rainwater Harvesting Techniques for Agricultural Production: A Case for Dodoma, Tanzania. Sokoine University of Agriculture, Morogoro.

PRASAD RAJENDRA, MERTIA RS and NARAIN P (2004) Khadin cultivation: A traditional runoff farming system in Indian desert needs sustainable management. J. Arid Environ. 58 87-96.

PRETTY J (1999) Can sustainable agriculture feed Africa? New evidence on progress. Process. Impacts Environ. Dev. Sustain. 1 (3-4).

PRETTY JN (1995) Regenerating Agriculture: Policies and Practice for Sustainability and Self-Reliance. Earthscan Ltd., London.

REIJNTJES C, HAVERKORT B and WATERS-BAYER A (1992) Farming for the Future: An Introduction to Low-External-Input and Sustainable Agriculture. Macmillan, London.
ROCKSTRÖM J (2000) Water resources management in smallholder farms in eastern and Southern Africa: An overview. Phys. Chem. Earth (B) 25 (3) 275-283.

SEPASKHAH AR and FOOLADMAND HR (2004) A computer model for design of microcatchment water harvesting systems for rain-fed vineyard. Agric. Water Manage. 64 213-232.

THOMSON S (1997) Adaptive Sampling in Behavioural Surveys, NIDA Research Monograph, Rockville, MD: National Institute of Drug Abuse. 296-319.

TSUBO M, WALKER S and HENSLEY (2005) Quantifying risk fore water harvesting under semi-arid conditions Part I Rainfall iintensity generation. Agric. Water Manage. 76 77-93.

WALKER S, TSUBO M and HENSLEY (2005) Quantifying risk fore water harvesting under semi-arid conditions Part II Crop yield simulation. Agric. Water Manage. 76 94-107. 